\title{
Strategies at SMP Muhammadiyah 9 Tanggulangin Boarding School in Online and Offline Learning During the Covid-19 Pandemic [Strategi SMP Muhammadiyah 9 Tanggulangin Boarding School dalam Pembelajaran Daring dan Luring dimasa Pandemic Covid-19]
}

\author{
Faradila Putri*, Muhlasin Amrullah \\ \{ faradilaputri.p@gmail.com, muhlasin1@gmail.com \} \\ Fakultas Psikologi dan Ilmu Pendidikan, Universitas Muhammadiyah Sidoarjo, Indonesia
}

\begin{abstract}
This study aims to determine the process of online learning and offline learning during the covid-19 pandemic at SMP Muhammadiyah 9 Tanggulangin Boarding School. The research method used is a qualitative method. Methods of collecting data by conducting interviews with one of the teachers who teach at the school. There are two kinds of learning carried out by SMP Muhammadiyah Tanggulangin, namely online learning and offline learning. Online learning began to be implemented when the government issued a warrant to study at home. However, in June 2020 the school decided to continue offline learning. This learning has special requirements so that students can enter school offline again. Until now, offline and online learning can run in a conducive and orderly manner.
\end{abstract}

Keywords: Online learning, Offline Learning, Covid-19 Pandemic Period

\begin{abstract}
Abstrak. Penelitian ini bertujuan untuk mengetahui proses pembelajaran daring dan pembelajaran luring saat pandemi covid-19 di SMP Muhammadiyah 9 Tanggulangin Boarding School. Metode penelitian yang digunakan adalah metode kualitatif. Metode pengumpulan data dengan melakukan wawancara kepada salah satu guru yang mengajar di sekolah tersebut. Pembelajaran yang diambil oleh SMP Muhammadiyah Tanggulangin ada dua macam, yaitu pembelajaran daring dan pembelajaran luring. Pembelajaran daring mulai diterapkan saat pemerintah mengeluarkan surat perintah untuk pembelajaran dirumah. Namun, Juni tahun 2020 sekolah tersebut memutuskan adanya pembelajaran luring kembali. Pembelajaran ini memiliki persyaratan khusus agar siswa bisa masuk sekolah secara offline kembali. Hingga saat ini pembelajaran luring maupun daring dapat berjalan dengan kondusif dan tertib.
\end{abstract}

Kata Kunci: Pembelajaran Daring, Pembelajaran Luring, Masa Pandemi Covid-19

\section{Pendahuluan}

Pendidikan merupakan usaha sadar dan terencana untuk memberikan bimbingan dan pertolongan dalam mengembangkan potensi anak baik jasmani maupun rohani yang dimana diberikan oleh orang dewasa kepada anak untuk mencapai kedewasaannya serta mencapai 
tujuan anak menjadi manusia yang beriman, berakhlak mulia, berilmu, kreatif dan mandiri yang dapat di terima di dalam masyarakat. Pendidikan akan memberikan pengalaman-pengalaman belajar di dalam program-program pendidikan formal, nonformal atau informal di sekolah. Sesuai yang diamanatkan dalam Undang-undang Sistem Pendidikan Nasional No. 20 Tahun 2003 pasal 3 menyatakan bahwa tujuan pendidikan nasional adalah untuk mengembangkan potensi peserta didik agar menjadi manusia yang beriman dan bertakwa kepada Tuhan Yang Maha Esa, berakhlak mulia sehat, berilmu, cakap, kreatif, mandiri dan menjadi warga negara yang demokratis serta bertanggung jawab [1]; [2]; [3]; [4]; [5].

Sekolah merupakan institusi yang diharapkan dapat membentuk karakter generasi muda. Dalam kontek ini pendidikan dimaknai sebagai proses untuk memanusiakan manusia untuk menjadi manusia dewasa seutuhnya. Melalui pendidikan di semaikan pola pikir, nilai-nilai, dan norma-norma di masyarakat.[6]; [7] Akan tetapi, dunia dikejutkan dengan adanya wabah penyakit yang disebabkan oleh virus yang bernama corona atau yang biasa dikenal dengan nama covid-19 (Corona Virus diseases-19). Kemunculan wabah ini pertama kali ditemukan di Kota Wuhan Provinsi Hubei Tiongkok pada 31 Desember 2019 dan kemudian mulai menyebar cepat ke seluruh dunia, termasuk Indonesia. WHO memutuskan pada tanggal 11 Maret 2020 bahwa virus ini ditetapkan sebagai wabah pandemi secara global. Di seluruh dunia, ratusan ribu manusia terpapar virus ini, bahkan virus ini menyebabkan puluhan ribu orang meninggal dunia setiap harinya. Tercatat beberapa negara yang memiliki kasus tertinggi terpapar wabah covid19 yaitu Italia, Amerika Serikat, Tiongkok, Spanyol, dan Iran.

Cara penularan virus ini melalui kontak sosial antara manusia sulit diprediksi dan juga tidak bisa dihindari sehingga penyebaran virus menjadi sangat pesat. Pada saat itu vaksin masih belum bisa ditemukan, sehingga cara memutus rantai penyebaran virus adalah dengan memakai masker, rajin mencuci tangan, tidak memegang wajah saat diluar rumah, dan pembatasan interaksi sosial (social distancing). Dengan penerapan social distancing (pembatasan interaksi sosial) berdampak juga dalam dunia pendidikan. Pemerintah membuat keputusan untuk meliburkan atau memindahkan proses pembelajaran yang tadinya di sekolah menjadi di rumah. Peralihan pembelajaran ini memaksa berbagai pihak untuk mengikuti alur yang sekiranya bisa ditempuh agar pembelajaran dapat berlangsung dengan cara memanfaatkan teknologi sebagai media pembelajaran daring. Penggunaan teknologi ini juga sebenarnya terdapat beberapa masalah seperti penguasaan teknologi yang masih rendah, keterbatasan sarana dan prasarana, jaringan internet, biaya, dan motivasi guru serta siswa yang menurun karena bosan menggunakan teknologi tersebut [8]; [9]; [10].

Istilah pembelajaran daring dan luring di perkenalkan di era teknologi informasi pada saat ini, pembelajaran daring merupakan singkatan dari pembelajaran dalam jaringan, atau pengganti istilah pembelajaran online yang sering kita gunakan dalam teknologi internet. [11]; [12]; [13] Menurut Ivanova dkk (2020) pembelajaran daring artinya adalah pembelajaran yang dilakukan secara online, menggunakan aplikasi pembelajaran maupun jejaring sosial. Pembelajaran daring merupakan pembelajaran yang dilakukan tanpa melakukan tatap muka, tetapi melalui platform yang telah tersedia. Segala bentuk materi pelajaran didistribusikan secara online, komunikasi juga dilakukan secara online, dan tes juga dilaksanakan secara online. Sistem pembelajaran melalui daring ini dibantu dengan beberapa aplikasi, seperti Google Classroom, Google Meet, Edmodo dan Zoom. Sedangkan menurut Hamid Muhammad sebagai plt. Dikdasmen Kemendikbud pembelajaran daring adalah pembelajaran yang menggunakan model interaktif berbasis internet dan Learning Manajemen System (LMS). "Pembelajaran daring ini dilakukan selama ini secara interaktif seperti Zoom, Google Meet. Itu salah satu (pembelajaran) yang kami sarankan agar ada interaksi antara guru dan murid di mana (catatannya) tak ada hambatan di gawai, internet, dan pulsa. Sedangkan pembelajaran luring merupakan singkatan dari 
pembelajaran di luar jaringan atau dengan istilah offline, artinya pembelajaran ini tidak lain merupakan pembelajaran konvensional yang sering digunakan oleh guru sebelum adanya pandemic covid 19 akan tetapi ada perubahan tertentu seperti jam belajarnya lebih singkat dan materinya sedikit.[14] Pembelajaran dengan metode Luring atau offline merupakan pembelajaran yang dilakukan di luar tatap muka oleh guru dan peserta didik, namun dilakukan secara offline yang berarti guru memberikan materi berupa tugas hardcopy kepada peserta didik kemudian dilaksanakan di luar sekolah [15].

Di masa pandemi covid 19 banyak cara dilakukan pihak sekolah untuk pembelajaran tetap berlangsung seperti menerapkan pembelajaran daring dan pembelajaran luring. Walaupun terkadang tujuan pembelajaran yang ingin disampaikan belum tercapai dengan baik, akan tetapi diharapkan dari proses tersebut diharapkan peserta didik mampu menerima pembelajaran baik pembelajaran daring ataupun pembelajaran luring. Termasuk upaya yang dilakukan sekolah untuk mencerdaskan peserta didiknya.[16]; [17]; [18]; [19]; [20] Selain ditandai dengan berkembangan zaman yang diiringi dengan berkembangannya dunia informasi dan teknologi tidak dapat dipungkiri lagi telah merubah tatanan kehidupan manusia saat ini. Dampak yang ditimbulkannya lebih dirasakan oleh para generasi muda. Sayangnya, perkembangan itu sebagian besar menjauhkan dari kehidupan yang islami. Muhammadiyah sebagai lembaga pelopor pendidikan di Indonesia telah terbukti turut serta dalam melahirkan generasi unggul yang berwawasan luas dalam ilmu pengetahuan dan teknologi. Namun hasil tersebut masih dianggap kurang karena kurangnya kader Islam Muhammadiyah militan yang dihasilkan dari lembaga pendidikan Muhammadiyah. Menyadari akan hal tersebut diatas serta memperhatikan akan minimnya jumlah pesantren yang dimiliki oleh Persyarikatan Muhammadiyah, maka Pimpinan Daerah Muhammadiyah Kabupaten Sidoarjo melalui Kelompok Bimbingan Ibadah haji (KBIH) “Jabal Nur” Sidoarjo sebagai salah satu Amal Usahanya, menggerakkan Jama'ah KBIH “Jabal Nur" Sidoarjo untuk mendirikan Pondok Pesantren An-Nur Sidoarjo (SMP Muhammadiyah 9 Boarding School Tanggulangin) di Desa Penatarsewu, Kecamatan Tanggulangin, Kabupaten Sidoarjo. Pondok Pesantren An-Nur Sidoarjo (SMP Muhammadiyah 9 Boarding School Tanggulangin) telah dirintis berdirinya sejak akhir tahun 2013 oleh pengurus KBIH "Jabal Nur" Sidoarjo periode tahun 2011-2016 dan pada tahun 2015 mulai eksis dengan membuka penerimaan santri baru untuk jenjang -Sekolah Menengah Pertama (SMP) dan menempati tanah wakaf milik Muhammadiyah.

\section{Metode Penelitia}

Penelitian ini menggunakan metode penelitian kualitatif deskriptif. Pendekatan kualitatif merupakan proses penelitian untuk memahami masalah-masalah sosial atau manusia dengan menganalisis kata-kata untuk menciptakan gambaran kompleks dan menyeluruh, serta melaporkan pandangan informasi terperinci yang diperoleh dari para sumber informasi dalam lingkungan alami. Pendekatan kualitatif juga bertujuan untuk menyelidiki, menemukan, menggambarkan, serta menjelaskan kualitas atau keistimewaan dari pengaruh sosial yang tidak dapat dijelaskan, diukur, atau digambarkan melalui pendekatan kuantitatif. Teknik pengambilan data dalam penelitian ini melalui wawancara, dokumentasi dan observasi, adapun triangulasi yang dipakai dalam penelitian ini adalah triangulasi teknik. Penggunaan metode kualitatif ini dimaksudkan untuk memperoleh gambaran mengenai strategi SMP Muhammadiyah 9 Tanggulangin Boarding School dalam pembelajaran daring dan luring di tengah pandemi covid19. 


\section{Hasil dan Pembahasan}

Penelitian ini diadakan di SMP Muhammadiyah 9 Tanggulangin Boarding School. Sekolah tersebut telah mengadakan pembelajaran daring dan pembelajaran luring sekitar bulan Juni tahun 2020. Sebelumnya sekolah ini hanya mengadakan pembelajaran daring selama kurang lebih selama 4 bulan semenjak pemerintah memutuskan pembelajaran dilakukan di rumah pada maret 2020.

Sistem pembelajaran daring dan luring ini mau tidak mau harus dilakukan karena peserta didik tidak bisa dibiarkan libur panjang karena menunggu wabah covid-19 ini hilang. Dalam pembelajaran daring dan luring memang memiliki keterbatasan dalam melakukan segala hal. Seperti contoh ketika pembelajaran luring kurang memiliki banyak waktu disebabkan karena waktu pembelajaran yang dikurangi dan materi yang bisa dijelaskan secara panjang harus dipersingkat. Untuk pembelajaran daring biasanya terkendala dari segi kualitas jaringan internet yang lambat dan kuota yang terbatas, jadi pertemuan tidak bisa dilakukan setiap hari di setiap mata pelajaran.

Dalam pembelajaran di masa pandemi ini, sekolah juga menggunakan berbagai cara supaya pembelajaran tetap berlangsung seperti pembelajaran luring. Pihak sekolah maupun guru dituntut harus cakap dalam menggunakan teknologi dan dituntut berpikir kreatif agar peserta didik tidak bosan dalam pembelajaran daring. Pihak guru pengajar biasanya menggunakan aplikasi pendukung untuk menunjang penyampaian materi pembelajaran, seperti menggunakan aplikasi WhatsApp, Google Classroom, Google Meet, Edmodo, dan Zoom. Supaya proses pembelajaran daring berjalan dengan lancar, maka guru sebelumnya harus memberikan arahan kepada peserta didik dan wali murid agar proses pembelajaran daring dapat berlangsung dengan kondusif. Jika guru mampu menyampaikan materi dengan menarik dan cara yang kreatif, maka peserta didik akan menjadi tertarik dan memiliki rasa penasaran terhadap materi yang disampaikan, sehingga hal tersebut membuat siswa aktif meski pembelajaran dilakukan secara daring.

Akan tetapi, terkadang tetap saja ada kendala dari siswa yang tidak bisa mengumpulkan tugas sekolah tepat waktu. Seperti contoh ketika cuaca sedang buruk atau kondisi daerah rumahnya yang tidak memadai jaringan internet akan terkendala jika ada pertemuan tatap muka online sehingga siswa tidak begitu paham dengan apa yang disampaikan pada saat itu. Dikarenakan kondisi pembelajaran yang dirasa kurang kondusif bagi pihak sekolah, maka sekolah berani melakukan pembelajaran tatap muka secara luring meski dengan syarat-syarat yang harus dilakukan.

Sekolah berani mengambil keputusan untuk melakukan dua model pembelajaran dengan syarat dan ketentuan yang sangat ketat. Sekolah memutuskan jika siswa yang masuk secara offline atau luring adalah siswa yang berdomisili Sidoarjo - Surabaya dan sudah melakukan swab test sebelum memasuki area sekolah ataupun asrama. Wali siswa juga tidak diperkenankan mengunjungi peserta didik selama pembelajaran sekolah masih berlangsung. Pihak sekolah juga membuat peraturan bahwa seluruh warga sekolah wajib mentaati protokol kesehatan, seperti memakai masker, tidak berkerumun, menjaga jarak, dan sering-sering mencuci tangan. Pembelajaran yang dilakukan di dalam kelas pun juga harus mentaati protokol kesehatan, seperti tetap menjaga jarak, membuka gorden dan jendela agar terkena sinar matahari, dan ketika pembelajaran berlangsung siswa dilarang berkeliaran di area sekolah ataupun ke asrama. Pihak sekolah juga memfasilitasi adanya tempat cuci tangan dan hand sanitizer di setiap sudut sekolah, sehingga siswa tidak perlu pergi jauh-jauh untuk sekedar cuci tangan di kamar mandi.

Bagi siswa yang tidak berkesempatan mengikuti pembelajaran secara offline atau secara luring, siswa dapat mengikuti pembelajaran secara online. Pembelajaran secara online juga tetap terkondisikan dengan baik, sama seperti pembelajaran secara offline, hanya saja tidak ada 
pertemuan tatap muka secara langsung. Peserta didik yang mengikuti pembelajaran online juga wajib mentaati peraturan dasar dari sekolah, seperti memakai seragam sesuai jadwal dan siswa harus mengerjakan dan mengumpulkan tugas sesuai dengan tenggat waktu yang sudah ditentukan. Meskipun pembelajaran berlangsung secara online, tidak ada kesenjangan dalam menyampaikan ilmu. Guru selalu menyampaikan hal yang sama ketika pembelajaran offline maupun online, sehingga murid yang mengikuti pembelajaran offline bisa mendapatkan ilmu yang sama seperti pembelajaran ketika offline.

\section{Kesimpulan}

Sejak kasus covid-19 mulai meningkat, seluruh lembaga pembelajaran tidak lagi melakukan aktivitas seperti biasa, karena pemerintah memberlakukan sistem di rumah saja, salah satu langkah yang tepat untuk mengatasi masalah ini adalah menggunakan teknologi jaringan dan informasi bagi sistem pembelajaran terutama di sekolah, dalam prosesnya banyak sekali kendala-kendala yang dihadapi oleh guru yang di mana pembelajaran daring ini baru pertama kali dilakukan seperti terkendala dengan sinyal dan lain-lain, akan tetapi kendala tersebut bukan menjadi penghalang untuk mendidik peserta didik, seiring berjalannya waktu pemerintah mengizinkan pihak sekolah untuk membuka kembali pembelajaran di sekolah maka terciptalah pembelajaran luring. Setiap pembekalan terkadang adanya kelebihan dan kekurangan termasuk pembelajaran daring dan luring di masa pandemi Covid-19 ini, akan tetapi dari sistem pembelajaran daring dan luring diharapkan guru untuk kreatif dalam mendidik peserta didik supaya keberhasilan pembelajaran bisa tercapai dengan baik atau efektif.

\section{Ucapan Terima Kasih}

Dengan terselesaikannya artikel jurnal ini penulis mengucapkan terima kasih yang sedalamdalamnya kepada Bapak Muhlasin Amrullah, S.Ud., M.Pd.I selaku dosen kami atas bimbingan, arahan dan koreksinya selama penyusunan dan penulisan artikel jurnal. Pihak sekolah serta guru yang telah memberikan saya izin untuk mendapatkan informasi sehingga artikel jurnal ini selesai.

\section{References}

[1] Sekretariat Negara, "Undang-Undang Sistem Pendidikan Nasional No 20 Tahun 2003”. Jakarta : 2013.

[2] Murkatik, K., Harapan, E., \& Wardiah, D., "The Influence of Professional and Pedagogic Competence on Teacher's Performance", Journal of Social Work and Science Education, 1.1, 58-69, 2020. Available: https://ejournal.karinosseff.org/index.php/jswse/article/view/10

[3] Abdullah, A., "Relationship the Work Culture and Training Programs Within Performance", International Journal of Progressive Sciences and Technologies (IJPSAT), 20.1, $2020 . \quad$ Available: http://www.ijpsat.es/index.php/ijpsat/article/view/1727

[4] Apriani, N., Fatonah, F., \& Oka, I. A. M., "Rancangan Sistem Pengolahan Sertifikat Berbasis Website Sebagai Upaya Untuk Peningkatan Evaluasi Kompetensi Safety Personil Di Lingkungan PT Angkasa Pura II (Persero)", Langit Biru: Jurnal Ilmiah 
Aviasi, 13.1, 17-28, 2020. Available: http://journal.ppicurug.ac.id/index.php/jurnalilmiah-aviasi/article/view/109

[5] Amalia, D., "Promoting Just Culture For Enhancing Safety Culture In Aerodrome Airside Operation”, International Journal of Scientific \& Technology Research, 8.10, 2019.

Available: https://www.academia.edu/45136835/Promoting_Just_Culture_For_Enhancing_Safet y_Culture_In_Aerodrome_Airside_Operation

[6] Rohma, S., Harapan, E., \& Wardiah, D., "The Influence of School-Based Management and Teacher's Professionalism toward Teacher's Performance", Journal of Social Work and Science Education, 1.1, 13-23, 2020. Available: https://ejournal.karinosseff.org/index.php/jswse/article/view/6

[7] Zulaiha, D., Lian, B., \& Mulyadi, M., "The Effect of Principal's Competence and Community Participation on the Quality of Educational Services", Journal of Social Work and Science Education, 1.1, 45-57, 2020. Available: https://ejournal.karinosseff.org/index.php/jswse/article/view/9

[8] Komalasari, K., Arafat, Y., \& Mulyadi, M, "Principal's Management Competencies in Improving the Quality of Education", Journal of Social Work and Science Education, 1.2: https://ejournal.karinosseff.org/index.php/jswse/article/view/11

[9] Hamzah, S., Yussof, M. H. B., \& Enriquez, A. A., "Togetherness in the Diversity of the Pancasila Ideology Frame", Journal of Social Work and Science Education, 1.1, 812, 2020.Available: http://ejournal.karinosseff.org/index.php/jswse/article/view/5

[10] Rohma, S., Harapan, E., \& Wardiah, D., "The Influence of School-Based Management and Teacher's Professionalism toward Teacher's Performance", Journal of Social Work and Science Education, 1.1, 13-23, 2020. Available: https://ejournal.karinosseff.org/index.php/jswse/article/view/6

[11] Ivanova, T., Gubanova, N., Shakirova, I., \& Masitoh, F., "Educational technology as one of the terms for enhancing public speaking skills", Universidad y Sociedad, 12.2, 154-159, 2020.2 Available: https://www.researchgate.net/publication/344225426_Educational_Technology_as_O ne_of_The_Terms_For_Enhancing_Public_Speaking_Skills

[12] Kristiawan, M., \& Muhaimin, M., "Teachers' Obstacles In Utilizing Information and Communication Technology", International Journal of Educational Review, 1.2, 5661, 2019. Available: https://ejournal.unib.ac.id/index.php/IJER/article/view/8846

[13] Kristiawan, M., "A Model for Upgrading Teachers Competence on Operating Computer as Assistant of Instruction", Global Journal of Human-Social Science Research, 14.5, 2014. Available: https://osf.io/m6wgn/download

[14] Prodjo, Wahyu Adityo. 200. "Pembelajaran Jarak Jauh bukan Pembelajaran Daring, Ini Penjelasannya" https://www.kompas.com/edu/read/2020/06/16/200131471/pembelajaran-jarak-jauhbukan-pembelajaran-daring-ini-penjelasannya. Diakses pada 24 April 2021.

[15] Kementerian Pendidikan dan Kebudayaan. "Kemendikbud Terbitkan Pedoman Penyelenggaraan Belajar dari Rumah, 28 Mei 2020, < https://www.kemdikbud.go.id/main/blog/2020/05/kemendikbud-terbitkan-pedomanpenyelenggaraan-belajar-dari-rumah $>$ [Diakses 24 April 2021]

[16] Zulaiha, D., Lian, B., \& Mulyadi, M., "The Effect of Principal's Competence and Community Participation on the Quality of Educational Services", Journal of Social Work and Science Education, 1.1, 45-57, 2020. Available: https://ejournal.karinosseff.org/index.php/jswse/article/view/9 
[17] Soleh, A. M., Tobari., Kesumawati, N., "Development of The Practical Manual As A Learning Media For Simulator Aircraft Rescue And Fire Fighting”, International Journal of Scientific \& Technology Research, 8.10, 2019. Available: http://www.ijstr.org/final-print/oct2019/Development-Of-The-Practical-Manual-AsA-Learning-Media-For-Simulator-Aircraft-Rescue-And-Fire-Fighting.pdf

[18] Septiani, V., \& Cahyono, D., "Education and Training Strategy in Palembang Aviation College", International Journal of Recent Technology and Engineering, 8.3, 2019. Available: http://scholar.google.com/citations?user=881Og84AAAAJ\&hl=id

[19] Nugraha, W., "Safety Documentation: A Communication Approach For Safety Management System In Aerodrome Operator", International Journal of Scientific \& Technology Research 8.11, 1705-1711, 2019. Available: http://www.ijstr.org/finalprint/nov2019/Safety-Documentation-A-Communication-Approach-For-SafetyManagement-System-In-Aerodrome-Operator.pdf

[20] Listiningrum, H. D., Wisetsri, W., \& Busan League, T. C. H. A. B. L. E., "Principal's Entrepreneurship Competence in Improving Teacher's Entrepreneurial Skill in High Schools", Journal of Social Work and Science Education, 1.1, 87-95, 2020. Available : https://ejournal.karinosseff.org/index.php/jswse/article/view/20 Media 